Archives de sciences sociales des religions

153 | janvier-mars 2011

Prisons et religions en Europe | Religions

amérindiennes et New Age

\title{
Prison Chaplaincy from a Scandinavian Perspective
}

Inger Furseth and Lene Maria van der Aa Kühle

\section{(2) OpenEdition \\ Journals}

Electronic version

URL: http://journals.openedition.org/assr/22784

DOI: $10.4000 /$ assr.22784

ISSN: $1777-5825$

Publisher

Éditions de l'EHESS

\section{Printed version}

Date of publication: 31 March 2011

Number of pages: 123-141

ISBN: 978-2-71322301-3

ISSN: 0335-5985

Electronic reference

Inger Furseth and Lene Maria van der Aa Kühle, «Prison Chaplaincy from a Scandinavian

Perspective ", Archives de sciences sociales des religions [Online], 153 | janvier-mars 2011, Online since

15 June 2011, connection on 19 April 2019. URL : http://journals.openedition.org/assr/22784 ; DOI :

10.4000/assr.22784 


\section{Inger Furseth, Lene Maria van der Aa Kühle}

\section{Prison Chaplaincy from a Scandinavian Perspective}

\section{Introduction}

European prisons increasingly hold inmate populations with diverse religious backgrounds due to globalization in terms of migration and globalized crime. The presence of religion in prison life has potential of aiding inmate rehabilitation, but it may also cause disagreements and conflicts. Although prison life in general is characterized by deprivation, international research shows that "Muslim prisoners feel particularly deprived of their rights if they are denied access to collective prayers, halal food, protection of modesty, and the spiritual support of suitably qualified Imams" (Beckford, Joly, Khosrokhavar, 2005: 279). The issue of religion in prison is therefore of utmost importance albeit treated differently in various countries. Prison authorities in some countries actively engage in ensuring that Muslim inmates can practice their religion, for instance by employing prison imams, providing halal food or by making space available for common prayers. In other countries, prison authorities are less involved in providing these accommodations, even if they recognize the inmates' right to freedom of religion. What are the possible explanations for these differences?

The debate on religion in prison may be seen as one aspect of general European processes of "accommodation of religious needs and religious personnel" (Maussen, 2006: 26). Within this context, debates on the management of religion have largely focused on Muslims and their needs regarding the establishment of mosques, Islamic education, provision of halal diets and more. On the one hand, European States operate in a global context where they are bound by international conventions on human rights, of which freedom of religion is central (Banchoff, Wuthnow, 2011). On the other hand, these conventions have to be applied in a variety of local political orders with different relations between religion and the State. Studies show that European States vary greatly in accommodating religious/Muslim needs (Modood et al., 2006). Scholars have attempted to explain these different policies by focusing on variables such as the relations between church and State (Fetzer, Soper, 2005), the formation of the nation State (Modood et al., 2006), or converging and diverging concepts of citizenship (Koenig, 2007). The accommodation of Muslims has to do with the relations between the State and religious minority groups. However, in order to 
understand the different ways in which a particular society creates opportunities as well as obstacles for the Muslim minority group it is not sufficient to focus on the State only (Maussen, 2006: 5). The notion of governance, that is, "mechanisms of action-coordination that provide active intentional capacities to regulation, co-regulation and self-regulation" (Bader, 2007: 873) moves the debate beyond the State and opens up for understanding regulation that exists beyond laws and is situated in praxis.

Our research questions regard the relationship between the general governance of religion in two different countries, Denmark and Norway, and the different ways in which Muslims in prisons are handled here. These two countries must look to the European Prison Rules and the United Nations (UN) Standard Minimum Rules for the Treatment of Prisoners, as they remain the key point of reference in designing and evaluating prison conditions (Furseth, 2001). These rules have to be applied in different local contexts, which result in great variety in policies regarding the opportunities for Muslims and other religious minorities to practice religion in prison. Some argue that these policies reflect the overall policies of managing religion in the particular countries in question. This was the focus of a three-year comparative study of France and Great Britain (Beckford, Joly, Khosrokhavar, 2005). The idea was to use the prison setting to "compare the French system of promoting the equal rights of all citizens of the Republic regardless of ethnicity and religion with the British tendency to favour the protection of minorities as a strategy for integrating them into a community of communities" (ibid.: 4). Beckford, Joly and Khosrokhavar conclude that the differences between the French and the British prison systems reflect the distinct modes of societal integration in the two countries, i.e. "the difference between assimilation at the cost of minority identities in France and pluralistic integration of communities at the cost of national unity in the UK" (ibid.: 295).

In this article we will question the idea that there is a necessary analogy between a country's general policy on religion and its governance of Muslims in prison. We will, first, give an outline of the church-State relations and official policies on religious diversity in Norway and Denmark, before we turn to the situation for Muslims in prisons in the two countries. Our argument is that there is a discrepancy between the official politics of religion and the governance of religion in prison, and we will explore how this discrepancy can be interpreted and explained.

\section{Religion, State and Muslims in Norway and Denmark}

There are several similar features between Denmark and Norway that make them useful in a comparative study of the role of religion in prisons. Both countries are fairly small with 5.5 millions in Denmark and 4.8 millions in Norway. 
In both countries, a large majority of the population belongs to State-supported Lutheran national churches. On January $1^{\text {st }} 2008,82,1 \%$ of Danes were members of the Evangelical Lutheran Church of Denmark (Statistics Denmark, 2010a). At the same time, a slightly smaller number, $81,7 \%$ of the Norwegian population, belonged to Church of Norway (Statistics Norway, 2008).

However, there are differing features between Denmark and Norway that make them useful for the comparative analysis as well. First, although the national Lutheran churches are State funded, their relations to the State differ. The Church of Denmark has little independence from the State: the highest authority in church matters is a politician, the Minister of Ecclesiastical affairs, and it lacks an efficient internal church administration and formal hierarchy, so no-one can speak on behalf of the church. The Church of Norway resembles its Danish relation in the sense that the highest authority in church matters is the Minister of Ecclesiastical affairs. However, during the $20^{\text {th }}$ Century several democratic reforms took place within the frames of the Church, so that numerous boards and committees are elected by members. In 1984 the democratically elected General Synod was established, which takes decisions regarding major internal issues. In addition, an efficient church bureaucracy is developed, so that the power of the Minister of Ecclesiastical affairs is reduced to providing the funds and appointing the bishops (Repstad, 2002). Even if church and State are not separated in Norway, there are pressures in that direction and the ties are loosening between the two (Stifoss-Hansse, Furseth, 2008). In contrast, a similar development is not taking place in Denmark.

Second, religious diversity exhibits different patterns in Denmark and Norway. In both countries, Muslims constitute the largest non-Christian religious minority group. However, Norway has a relatively large group of Christians who are members of free churches. In 2009, this group amounted to 54\% (235.000) of all members in faith and worldview communities outside the Church of Norway (Statistics Norway, 2009a). In Denmark, Christian groups outside the Church of Denmark are marginal. As a result, the situation in Norway appears to be less polarized in the area of religion than is the case in Denmark.

Third, the status and visibility of Islam also vary in the two countries. Regarding the size of the Muslim population, only estimates exist, as religious affiliation is not registered in either country. In Denmark, it is estimated that in 2009 about $4 \%$ (220.000) of the Danish population is Muslim (Jacobsen, 2009: 98). Turkish Muslims (about 25\%) constitute the largest group, followed by Iraqis (12\%), Lebanese $(11 \%)$, Pakistanis $(8 \%)$ and Somalis (8\%) (Jacobsen, 2009: 98). In 2009 Muslims constitute about 3\% (150.000) of the Norwegian population (Jacobsen, Leirvik, 2009: 257). This year, more than 80.000 persons (about $55 \%$ of the estimate of persons with a Muslim background) were members of Muslim organisations (ibid.: 257). Pakistani Muslims constitute the largest 
group, followed by Iraqis, Somalis, Iranians and Turks. Due to the different demographics of the Muslim population in Denmark and Norway, the Muslim communities of the two countries differ. Whereas the Turkish "State Islam" Diyanet has helped the large group of Muslim Danes of Turkish origin to set up mosques, the development of Islam in Norway has been more affected by the Pakistani background of many Muslim Norwegians.

Even if the amount of Muslims is larger in Denmark, Islam has an ambiguous status here. On the one hand, 58 Muslim congregations within 19 organisations have acquired positions as acknowledged religious communities (Kühle, 2009). ${ }^{1}$ This status enables them to obtain licence to perform weddings and entitles them to other privileges, such as tax deductions. Yet, few acknowledged Muslim communities take advantage of these privileges and they complain about the lack of a real recognition of the Muslim community. In contrast, Islam has a more clearly defined status in Norway. Here, Muslim faith communities are registered on an equal footing and with equal rights as other faith and worldview communities. The Muslim Council of Norway was established in 1993, whereas in Denmark, United Council of Muslims was not founded until 2006 and Danish Muslim Union was not established until 2008 (Jacobsen, 2009: 102; Jacobsen, Leirvik, 2009: 259). Neither organisation works efficiently as representatives of Danish Muslims.

Furthermore, Islam is more visible in Norway than in Denmark. There are four mosques in Norway that are built for this purpose with visible minarets, whereas the mosques in Denmark are store-fronts that cannot be recognized as such from the outside, with the exception of the Ahmadiyya mosque in Hvidovre. In the media, Muslim voices are more often included in Norway than in Denmark, even if the debates are fairly similar (Christensen, 2010: 130). The themes center increasingly on radicalisation and terrorism, sparked by arrests on terrorism charges in both countries.

Finally, the two countries exhibit different systems for governing religious diversity. In Denmark no religious group apart from the Church of Denmark receives subsidies directly from the State. However, religious communities may apply for a status as acknowledged religious communities in which case donations to the religious community is tax-deductible for the donator. In Norway, all registered faith and worldview (e.g. humanist) communities receive public funding from the State according to their number of registered members. In principle, all faith and worldview communities receive the same amount per member as does the Church of Norway.

In spite of these differences, Norway and Denmark tend to be categorized as similar cases in the international research literature. One example is David Martin's seminal work on secularisation in Western Europe that characterized

1. Since this article was written one additional congregation within one specific Muslim organisation has been registered. 
both Denmark and Norway as weak cases of Anglo-American pluralism (Martin, 1979: 23). In the 1970s both countries exhibited little pluralism, harmonious coexistence of State and church, high levels of church membership, low church attendance, and strong presence of Social Democracy (Martin, 1979: 34-35). Another example is from the 1990s debates on welfare regimes, where both countries were situated comfortably within the Social Democratic cluster, separate from the Liberal and Conservative regimes dominant in the US and Germany (Esping-Andersen, 1990). In fact, a recent study based on quantitative interview data claimed that Denmark and Norway along with Sweden have the weakest racial and religious symbolic boundaries in Europe. These facts are explained by a relatively strong antiracist discourse, positive contact between natives and people of non-European origin, and the absence of competition between them (Bail, 2008: 55). In recent years Denmark and Norway have, however, along with Germany and Great Britain moved towards increasingly conflictual processes of realigning religion in the public sphere (Minkenberg, 2007: 900). Finally, in terms of criminology and penal history Denmark and Norway participate in the same "Scandinavian cluster", characterised by low imprisonment rates $(70$ per 100.000), even if Denmark and Sweden are perceived to be slightly more treatment-oriented than Norway and Finland (Christie, 2001; Lappi-Seppälä, 2007: 218).

However, there are exceptions to this rule, as some recent studies emphasise the differences between Norway and Denmark. One study describes Norway as a country that actively seeks to engage in "religious dialogue" politics, whereas Danish authorities exhibit "more dismissive policies" (Siim, Skjeie, 2008: 329). This study also argues that while State funded religion in Norway now forms the single most important basis for immigrant organization, Denmark is a country with the least official interest in developing a dialogue with its Muslim population (ibid.: 329). Other studies point out that anti-Muslim sentiments have become a more prominent part of the political discourse in Denmark than in Norway and Sweden (Larsson, 2009: 4). Indeed, media coverage of immigrants in Denmark tends to be negative and framed in nationalistic terms (Horsti, 2008: 282). Denmark has been said to have "the most virulent public anti-Islamic discourse of all the European countries" (Bowen, 2007: 1014). Based on these studies, one would expect that politics managing Islam in prisons would be more accommodating in Norway than in Denmark. It is to this issue that we will now turn.

\section{Muslims in Norwegian prisons}

The Norwegian law on individual registration of June 1978 requires a license to register information about race, religion and political affiliation. No statistical information is therefore available on the number of Muslims in the Norwegian 
prison system. In 2007 the total number of convicted prison inmates was 2594 and $85 \%$ are Norwegian citizens. Altogether 110 nations were represented in Norwegian prisons this year (Kriminalomsorgen, 2008: 26; Statistics Norway, $2009 b)$. The number of Muslims in Norwegian prisons varies greatly. Whereas many small prisons located in towns and villages throughout the country have few, if any, Muslims, the largest Muslim prison populations are in the prisons of Ullersmo, Oslo, Halden, and Bergen. Ullersmo prison had 180 inmates in 2010 (Kriminalomsorgen, 2010). In 2009 a prison chaplain here estimated that $40-50 \%$ were Muslim, a growth of about $10 \%$ during the past ten years (Furseth, 2001). Oslo prison is the largest in the country when it comes to number of inmates. In 2010 there were 400 inmates here from 57 different countries (Kriminalomsorgen, 2010). A prison clergy estimated in 2010 that $15-20 \%$ of the inmates were Muslims, which indicates that the amount of Muslims has been relatively stable during the past decade. Halden prison opened in 2010. As a modern prison that emphasizes rehabilitation through education, it houses 248 inmates of whom $15-20 \%$ are estimated by the chaplain to be Muslim. Bergen prison opened in 1990 and houses about 200 inmates, of whom 10\% were estimated by a chaplain in 2010 to be Muslims, a reduction of $5 \%$ during the past decade. The chaplains in these prisons estimate the amount of Muslims to vary between $10-50 \%$ with an average of $20-25 \%$ in these four prisons. This means that the Muslim population is of a noteworthy size.

The Muslims prison population is greatly differentiated. Some are immigrants whereas others are of immigrant descent with family origins from different parts of the world, such as Europe, Asia, and North and Central Africa. While some are born and raised in Norway, others are caught on the border and have never lived here before. Apart from their religion, Muslim inmates share few common factors. They belong to different traditions within Islam and they vary regarding nationality, language, cultural traditions, residence, and reasons for imprisonment. At the same time, they constitute the largest religious minority in Norwegian prisons.

Which arrangements are made to enable prison inmates to practice their religion? When it comes to food, prisons make different forms of accommodations. Some prisons have self-catering, where the inmates cook their own food and orders can be made for special ingredients. Other prisons give the inmates options, and one option is halal. Again other prisons give the inmates options between vegetarian, pork-free, or pork included menus, but no halal meat is served. The opportunity to practice religion during the work day is fairly limited. Most inmates have to work or attend school, and The Execution of Sentences Act (Lov om giennomføring av straff) from May 18, 2001 nr. 21 states that, "The Correctional Services shall give prisoners opportunities to practice their religion and philosophy of life" but that this practice preferably shall take place during recess or after work hours (Odelstingspreposisjon nr. 5, 2001: 157). 
There is a growing concern with security in this Act and little emphasis is on the rights of religious minorities (Furseth, 2006: 219).

The Church of Norway prison chaplaincy dates back to the late 1800 s. Until the spring of 2000 , prison chaplains were officially appointed by a regional council consisting of the director for the prison district, the local bishop in the Church of Norway, and a member of the union that organizes the majority of chaplains in the diocese. In 2000, the authority for hiring prison chaplains was transferred to the council of the local diocese. Since 2004, the prison chaplaincy is no longer financed directly by the State, but through the budget of the Church of Norway (Aftenposten, 2006: 2). This change is significant, as contemporary Norwegian prison chaplains are neither financed nor hired by the prisons, but by the Church. The number of prison chaplains increased from seven in 1994, eighteen in 2000, to thirty-three in 2009 (Kirkens informasjonstjeneste, 2009: 318-320). The prison chaplaincy is considered to be an integrated part of the work of the Church of Norway. All prison chaplains are ordained clergymen of the Church of Norway, although most of them have additional clinical pastoral training.

Since the 1990s, several imams have visited Norwegian prisons on a voluntary or $a d-h o c$ basis. It is common practice among the prison chaplains, and often set out in their job descriptions, that they are to initiate contact with representatives of other faith communities on behalf of inmates, which many do (Furseth, 2001). However, several difficulties have been related to this arrangement. Many imams do not have the time to visit prisons on a voluntary basis in addition to a busy schedule in the mosques (Aftenposten, 2006). Other imams have shown little interest. Again others are interested but not permitted, due to a growing concern with security and fear of radical Islam in prisons. A letter written by representatives from the Ministry of Culture and the Ministry of Justice dated July 16, 2009 regarding "Cooperation on faith- and worldview services in prisons" claimed that the "aim is to organize these services so that all inmates get equal opportunities for religious and worldview practices" (Kulturdepartementet, 2009). Recently, Oslo prison has been successful in making arrangements with two mosques and their imams come and arrange Friday prayers every week on a voluntary basis. This arrangement has lasted for about three years. In the recently opened Halden prison, similar arrangements have been made. Apart from these voluntary arrangements, little has been done to accommodate the large group of Muslim inmates. It is still largely the Lutheran prison chaplains who function as facilitators in the sense that they attempt to enable Muslims to practice their religion in prison. They also function as intermediaries or brokers between inmates of Muslim faith, the prison management, official representatives of the Muslim faith, and they negotiate between these parties. 


\section{Muslims in Danish prisons}

There are 14 prisons, 40 remand prisons and about 30 other institutions run by the prison service in Denmark. In 2009 there were 2.230 convicted prison inmates in Danish prisons (Kriminalforsorgen, 2009: 7). Most inmates are Danish citizens and born and raised in Denmark, but a report from November 2008 shows that about $22 \%$ do, as the prison service phrases, "have another national background than Danish". 3\% are foreigners without any prior relation to Denmark, $15 \%$ are immigrants and $4 \%$ are children of immigrants (Kriminalforsorgen, 2008: 28). Inmates with a background in Turkey, Lebanon, Iraq and Somalia are well-represented in the statistics. This means that the number of inmates in Danish prisons with a Muslim background now constitutes about 19\% (Avisen.dk, 2008). This makes Muslims by far the largest religious minority in Danish prisons with only small groups of inmates belonging to Buddhism, Catholicism, Hinduism, and Nordic paganism or Satanism (Kriminalforsorgen, 2006). ${ }^{2}$ There are great variations in the number of Muslim inmates in the different prisons. They constitute perhaps $1 / 3$ in some prisons, for instance the prisons of Copenhagen, while some countryside prisons hold almost none. Numbers are estimates as there is neither tradition nor procedures for registration of religious adherence.

Since the establishment of the modern Danish prison system there has been a tradition for employment of prison chaplains from the Lutheran Evangelical Church of Denmark. In $19^{\text {th }}$ century prison ideology, the chaplain was crucial for providing moral improvement and healing of inmates. During the $20^{\text {th }}$ century, the impact of the prison chaplains diminished, as new groups, such as social workers, teachers, and psychologists were employed and prison inmates attached less importance to religion. In the 1970s, the number of prison chaplains declined and the system of prison chaplaincy was almost abolished. Only the intense lobbying by one chaplain disrupted the plans of the prison authorities to remove the chaplain from an old prison in Denmark, the prison of Horsens (Kühle, 2004, 2006). In the 1980s the tides changed and the Church of Denmark became involved in erecting new chaplaincy positions so that the number increased from six to thirteen (Kühle, 2006: 201). The prison chaplain is generally considered to be a representative for all religions and is therefore directly involved in issues regarding the practice of Islam. Most chaplains devote much time and effort to provide for the religious needs of Muslim inmates. A study of religion in prison supports this notion (Kühle, 2004). For example, one prison chaplain acted as a driver when Muslim inmates wanted to visit the mosque.

2. In the study of 2.353 inmates, 1.379 gave their religious preference as "Christian", 441 answered "Muslim", while 47 said "Buddhist", 16 "Hindu”, 13 "Jew", while 457 said "other". The study was not designed to tap a Catholic group, but 29 had added Catholic on their forms. The response rate was 58\% (Kriminalforsorgen, 2006: 16-18). 
Another chaplain helped to establish a Muslim prayer room in a separate corner of the prison church. A third chaplain aided in forming a Muslim council, which acted as an agency for Muslim interests in that particular prison (Kühle, 2004). The position of the Evangelical-Lutheran chaplains resembles the arrangement of facilitation and "brokerage", which has been described in British and Norwegian prisons (Beckford, Gilliat, 1998; Furseth, 2001).

The Church of Denmark prison chaplains have, however, within the last ten years been endowed with new colleagues. Since the early 1970s, imams have visited Danish prisons on a voluntary and ad hoc basis. In the mid-1990s, prisons began to employ imams in various permanent positions, where khutba and counselling could be part of the job. In 2002 one imam achieved the official title of prison imam (Kühle, 2004: 222). Today three imams are employed. One position is full-time, while the other two amount to a few hours a week. These employments are remarkable since this is the first time Danish authorities are employing representatives of minorities for religious positions. In 2006 Danish prison authorities published a report suggesting that in total 22 imams should be employed in part-time positions. ${ }^{3}$ Although the employment would not amount to more than three full-time positions, this report clearly signals the commitment of prison authorities to include (and to fund) Muslim chaplaincies.

One explanation for the new policy is that the system of voluntary Muslim chaplaincy failed. Prisons chaplains and prison inspectors often made great efforts to find imams who were willing to visit prisons on a voluntary basis, but they were in most cases unsuccessful. When imams did agree to visit prisons, the arrangements often turned out to be short-lived. In some cases the inmates did not want the imam to come as they felt he was scolding them. An additional problem was the lack of co-ordination of Muslim prison work. The chaplains were willing to distribute al-Qur'an to inmates, but they were often unable to find donors. Prison authorities were generally willing to exempt inmates from work on religious holidays, but they faced difficulties of knowing when, as information from the inmates was sometimes unreliable. The employment of Muslim prison chaplains is believed to solve all these problems and more.

Danish prisons generally attempt to accommodate the basic needs of Muslim inmates. Almost all Danish prisons have self-catering, ${ }^{4}$ which means that the prison inmates cook their own food from groceries bought in the prison store. The same flexibility regards work. Though most prisoners do have to work in prison, Muslim inmates are often allowed to leave early on Fridays or not to work on holidays. Inmates borrow books from the local library, and usually

3. http://www.ft.dk/samling/20061/almdel/REU/Bilag/227/335361.PDF

4. Remand prisons do not have self-catering but has special diets available for diabetics, vegetarians and Muslims. http://www.kriminalforsorgen.dk/Default.aspx?ID=19\&M=NewsV2\&PID= $18 \&$ NewsID=22 
they may order books from other libraries. However, their situation is precarious in the sense that they are dependent on the goodwill of the prison authorities and the prison chaplain. Traditionally Muslim inmates have not been viewed as particularly problematic. A 2005-report on ethnic minorities in Danish prisons showed that older ethnic minority inmates (of whom many come from Muslim countries) are perceived to be "well-behaved". This is explained by the fact that they tend to be first offenders without substance abuse problems (Kriminalforsorgen, 2005: 14). Young inmates with a Muslim background, however, deal drugs, cause trouble and occasionally use Islam to challenge prison authorities (Kriminalforsorgen, 2005: 39). The report concludes by proposing a compulsory course on Islam and Muslim culture for prison personnel (Kriminalforsorgen, 2005: 45). A 2007-report focuses on one specific prison in Copenhagen and finds that inmates with a Muslim background in average have the highest average number of disciplinary cases. This shows that some Muslim inmates have no disciplinary quarrels with prison authorities, whereas others are very challenging (Knap, Graunbøl, 2007: 9).

The report and statements from the Danish prison authorities suggest that rehabilitation in a broader sense is one reason for employing prison imams. Deputy manager Tove Brøchner in Danish Prison and Probation Service explains in a newspaper interview that the decision to employ more imams in prisons is based on a concern for freedom of religion as well as rehabilitation and counteraction against radicalization: "With more imams more Muslim inmates will attend Friday prayers. At the same time we emphasise that imams must do pastoral care and counteract radicalization among young Muslims” (Avisen, 2008).

\section{Comparing the treatment of Muslims in prisons in Denmark and Norway}

The accommodation of religion in prisons in Denmark and Norway are similar on some issues. Both countries have a history of prison chaplaincy and the number of Evangelical Lutheran chaplains working in prisons has grown during the past decades. These chaplains have, apart from providing services to all prison inmates, functioned as facilitators and brokers on behalf of the Muslim prison populations. In addition, prisons in both countries seem to accommodate various ethnic and religious minorities when it comes to diet, as most inmates seem to have various options in this area.

However, the major difference between the two countries lies in the employment of prison chaplains and imams. In spite of the fact that the Norwegian population is slightly smaller than the Danish, Norway has a much larger number of prison chaplains (33 in 2009) than Denmark has (15 in 2009). This means that Norwegian prisons are more densely populated with Lutheran clergy than Danish prisons are. A striking contrast is that no prison imam is employed in 
Norwegian prisons, whereas Denmark has employed imams in three prisons. Indeed, the plan in Denmark implies that the number of prison imams will exceed that of prison chaplains (even if most positions will be part-time). Although the differences between Norwegian and Danish accommodation of Islam in prisons are not that large, they are substantial none the less. The fact that Danish prison authorities have employed prison imams, while there is no similar arrangement in Norway is surprising, given the fact that Danish general policies towards Islam are considered less accommodating than Norwegian policies. What are the possible explanations for these differences?

One factor that may help explain the different policies is related to the perceived urgency of radicalisation of Islam in the two countries. Since 2005, six persons in Denmark have been convicted of planning terrorist plots (the socalled Glostrup, Odense and Glasvej cases) and several others have been found guilty of proliferating jihadist literature and of attacking cartoonist Kurt Westergaard, whose caricature of the prophet is the best-known of the twelve caricatures which caused the Danish cartoon crisis. Several international terror plots have revealed that Denmark, due to the cartoon crisis, has become a centre of attention for international jihadism.

The issue of radicalisation of Islam has only recently caught the attention of Norwegian media. In February 2010, the publication of a new cartoon of the Prophet Muhammad was met by outrage from Norwegian Muslims. After a demonstration, radical Islamist views were for the first time voiced in public when Mohyeldeen Mohammad, a student in his twenties, warned that unless Muslims were respected, "Perhaps we will have September 11 or July 7 on Norwegian ground. This is not a threat, but a warning." Minister of Justice Knut Storberget responded by expressing concern for the growing recruitment to radical Islamic groups (Aftenposten 02.15.10; Dagbladet 02.12.10). The large majority of Norwegian Muslims condemned Mohammad's statement. However, the debate continued when the police later arrested three men on the suspicion of planning terrorist attacks.

Beckford, Joly and Khosrokhavar suggest that the presence of more prison imams in Great Britain than in France is related to the perceived urgency of religious extremism. Great Britain has witnessed a lower level of threat from Islam than France, where Islam was considered to be more dependent upon foreign interest, with a widespread use of foreign Islamic literature and few home-bred imams (Beckford, Joly, Khosrokhavar, 2005: 294). The perceived threat may have impeded the employment of prison imams in France. The comparison between Norway and Denmark points to almost the opposite. Although a study of debates in the media and the parliaments in Scandinavia show that the perceived level of threat of Islam is similar in Denmark and Norway (Christensen, 2010) the discourse on radical Islam began earlier in Denmark than in Norway. In Denmark a government action plan on preventing radicalization 
was launched in 2009. ${ }^{5}$ A proposal to employ more prison imams was part of the first version of the action plan, while the final version suggested that religious personnel (which would include prison imams) should be engaged in the prevention effort without actually endorsing the employment of more imams. Emphasis is on control, and the fact that money is allotted for "intensified surveillance of religious services in prisons" ${ }^{6}$ suggests that the purpose of employing prison imams has to do with security and prevention of radicalization, rather than the provision of religious freedom. The final version of the action plan reflects a compromise between the needs of the prison to control and re-socialise its Muslim prison population, and security concerns voiced in public debates.

The issue of security is also of growing importance in Norwegian prisons. The Prison Act of 1958 only mentions religion once, that is, in the statement that "One chaplain shall work at each institution" (Fridhov et al., 1994: 19). In contrast, the Norwegian Execution of Sentences Act (Lov om giennomforing av straff) of 2001 states that religious practice "can be limited in a maximum prison ward." The prescriptions (Forskrift til lov om straffegjennomføring) of 2002, paragraph 5-6, presents specific regulations for maximum security inmates:

Conversations with ministers, pastors, spiritual leaders or other worldview advisors shall mainly take place according to the same control as other visits. Local level can diminish the control regarding religious activities when consent is given from regiona level.

One would expect that in an increasingly multi-religious Norway, prison laws and regulations would consider and expand the opportunities for religious minorities to practice their religion in prison. Instead, the trend has gone in an opposite direction. The religious rights of inmates have clearly been restricted in the new Act. In addition, the threat of radical Islam is used in different ways in the two countries. In Denmark, the proposal to employ more prison imams is related to efforts of preventing radicalization. In Norway, a prison clergy in a maximum security prison recently stated that the prison authorities used the fear of radical Islam as an argument against hiring prison imams. For them, the fear of imams spreading radical Islam to the Muslim population made them even more negative to the issue of prison imams and called it a "non-issue".

Another important factor that may help explain the different policies in Denmark and Norway is related to the sources of funding prison chaplains and imams. In Denmark, both groups are funded and hired ${ }^{7}$ by the prison authorities. It fits well with the weak church structures that the State is in charge of

5. http://www.nyidanmark.dk/NR/rdonlyres/4443E64E-3DEA-49B2-8E19-B4380D52F1D3/0/ handlingsplan_radikalisering_2009.pdf p. 23.

6. http://www.kriminalforsorgen.dk/Default.aspx?ID=267

7. In fact, formally it is the Minister of Ecclesiastical Affairs who hires the prison chaplains, but it is the prison director who does interviews with the candidates and on behalf of these writes recommandations to the Minister of Ecclesiastical Affairs, who then does the formal employment. 
this. In Norway, the authority of hiring prison chaplains was transferred to the council of the local diocese in 2000, which means that the chaplains are hired and funded by the Church of Norway. This arrangement is used by the State authorities to argue against State funding of prison imams. Since all faith communities in principle receive the same amount of State support per member, State secretary Randi Øverland in Ministry of Culture and Church said in 2006: "Muslim faith communities must prioritize. Large [Muslim] congregations can afford to pay for a prison imam if they think it is important. Muslim faith communities cannot receive any more public support than other communities" (Aftenposten, 2006: 2). Indeed, the sheer size and budget of the Church of Norway, as well as its established institution of prison chaplaincy, puts this faith community in a favourable position within the prison system. The question is if it is reasonable to demand that Muslim communities, which total about 84.000 members in 2008, should provide similar types of services that the Church of Norway does, which totals about 3.9 million members in 2008. By demanding that the faith communities finance prison chaplains and imams, the privileged position of the Church of Norway is upheld in the prisons.

Our comparative study raises the question: To which extent are State policies of regulating religious minorities coherent and consistent? Beckford, Joly and Khosrokhavar find that the policies of prisons as agencies of the State correspond well with the general policies of religion of France and Britain (2005: 271). Our study suggests that policies of governance are not necessarily coherent and consistent. A common mistake in comparative research is to simplify and ignore heterogeneity (Bader, 2007). Indeed, it is dubious to assume that one country has one single profile of governance only. Perhaps it cannot be assumed that Norway in all matters has more multi-religious policies than Denmark does. When it comes to the practice of halal slaughter, for example, Denmark belongs to the majority of European countries where halal slaughter holds a dispensatory status in regard to legislation on animal protection, whereas Norwegian legislation allows no exemption from pre-stunning (Bergeaud-Blackler, 2007: 966). Danish policies on funding private Muslim schools are also one of the most "favourable circumstances of any European country for the establishment of Muslim schools" (Nielsen, 2004: 82). Many aspects of the governance of the Muslim population in Denmark do not correspond well with the general vigorous and tough debates on Islam in the public sphere and may not be completely consistent. Most schools will for instance accept the absence of pupils on the first two days of Eid and a few schools are even closed on these days. Some hospitals have separate wash rooms for the preparation of Muslim burials and one hospital has even employed a hospital imam. Often the cartoon crisis in 20052006 is simply seen as a sign of the rise of Islamophobia and neo-nationalism in Denmark. However, Danish society was vastly divided on this issue and about 
half of the population found that the cartoons should not have been published (Riis, 2007). Although the neo-nationalist party Dansk Folkeparti, Denmark's third largest party after the 2007 election and a supporting party to the government is important, they have not succeeded in the implementation of their policies in all sectors of Danish society.

The arrangement of hiring imams in Danish prisons was initiated by a Lutheran chaplain working in Copenhagen prisons, and the employment has hardly been discussed in public. When provisions for Muslims have been discussed, the views are mainly negative and often seen as an aspect of an on-going "Islamisation" of Denmark. A member of the parliament for Dansk Folkeparti, for example, complained that:

we succumb to Muslim customs, not only in the kindergartens with halal slaughtered meat, etc., but now also, in prisons, where you give Muslims freedom to celebrate a national holiday for them, while the Christian prisoners have to work hard to earn their daily cigarettes and necessities; I think it is totally unreasonable (Kim Christiansen, Discussion of U138, October 20 ${ }^{\text {th }} 2006$ ).

However, he was opposed by the Minister of Justice who simply referred to the law on enforcement and the European prison Rules. ${ }^{8}$ It is well-known that media debates on prisons often prompt reactions in regard to legislation, in particular when it comes to pressures for higher penalties (Lappi-Seppälä, 2007: 253). Yet the governance of Danish prisons seems largely to be determined by the internal needs of the prison system rather than by the logic of public debates.

In Norway, the issue of imams in prisons is not an object of public debate. In some instances, the media have reported that the lack of accommodation for Muslims in prisons causes problems for these inmates. However, as soon as this issue was described as a responsibility of the Muslim community and not the State, the debate went dead and it is largely seen as a non-issue. This may lead one to conclude that the issue of imams in prisons in Norway largely has to do with questions of funding and not public policies on multi-religious society. The argument here is that this is hardly the case. Many public institutions do accommodate Muslims in Norway, as they do in Denmark. For example, public schools accept the absence of students to celebrate Eid. Some public hospitals have separate wash rooms for the preparation of Muslim burials, and some have religiously neutral rooms used for rituals and services. Public institutions like the military and public hospitals also hire and fund chaplains from the Church of Norway, but they do not hire nor fund imams (Furseth, 2001; 2003; 2009). Therefore, imams in prisons must be seen as a more general issue of public policies regarding the opportunities for religious minorities to practice and receive religious care in public institutions.

8. http://www.ft.dk/dokumenter/tingdok.aspx?/samling/20061/spoergsmaal/S305/index.htm 


\section{Conclusion}

When compared, Denmark and Norway often come out as relatively similar countries. However, we have attempted to show that when it comes to the governance of Muslims in prison there is a marked difference between the two countries. In Denmark there are prison imams paid by prison authorities and a growing number of prison imams are to be employed in the coming years. Here, prison imams are seen as a responsibility of the State. In Norway, it is up to the Muslim community to employ imams. Therefore, this issue is not viewed as a responsibility of the State. This may be surprising as Denmark compared to Norway is a country where debates on the role of Islam in society often runs higher and is more polarized. The difference can partly be explained with reference to variations regarding church-State relations, the system of funding imams in prisons, and the importance of the discourse on radicalization. The closer relationship between church and State in Denmark makes it more likely for the State to engage in the employment of religious personnel, including personnel from minority religions. The discourse on radicalisation here also provides legitimation for State funded prison imams due to their role in countering radicalisation. Yet the differences between the two countries raise the question of the governance of religion. In spite of a more polarized debate and seemingly more assimilationist public policies in Denmark than in Norway, Denmark demonstrates in some areas policies and practices that are more accommodating to Muslims than Norway does. This shows that there is no necessary direct link between overall policies on multi-religious societies and the actual accommodation of Muslims and other religious minorities in public institutions like the prisons.

Inger FURSETH KIFO, Oslo, Norvège Inger.Furseth@kifo.no Lene Maria van der Aa KÜHLE Aarhus University, Denmark

LK@teo.au.dk

\section{Bibliography}

Aftenposten, 19 November 2006, "Vil inn i fengslene. Økende antall muslimer bak murene". [Wants to enter the prisons. Growing number of Muslims behind bar]

Aftenposten, 15 February 2010, "Justisministeren bekymret for mer radikal islam" [Minister of Justice concerned about more radical Islam], Available from http://www. aftenposten.no/nyheter/iriks/article3519045.ece [Accessed November 9. 2010]

Avisen:DK 3 July 2008, “Muslimske indsatte får mere fredagsbørn” [Muslim inmates get more Friday prayer]. Available from http://avisen.dk/danske-faengsler-faar-merefredagsboen_13464.aspx [Accessed November 19. 2009] 
BADER Veit, 2007, “The Governance of Islam in Europe: The Perils of Modelling”, Journal of Ethnic and Migration Studies, 33-6, pp. 871-886.

BaIL Christopher A., 2008, "The Configuration of Symbolic Boundaries against Immigrants in Europe", American Sociological Review, 73, pp. 37-59.

Banchoff, Thomas, Wuthnow Robert, (eds.), 2011, Religion and the Global Politics of Human Rights, Oxford, Oxford University Press.

Bergeaud-Blackler Florence, 2007, "New Challenges for Islamic Ritual Slaughter: A European Perspective", Journal of Ethnic and Migration Studies, 33-6, pp. 965-980.

Beckford James A., Gilliat Sophie, 1998, Religion in Prison. Equal Rites in a Multifaith Society, Cambridge, Cambridge University Press.

Beckford James, Joly Daniele, Khosrokhavar Farhad, 2005, Muslims in prison: Challenge and change in Britain and France, Basingtoke, Palgrave Macmillan.

Bowen John, 2007, "A View from France on the Internal Complexity of National Models", Journal of Ethnic and Migration Studies, 33-6, pp. 1003-1016.

Christensen Henrik Reintoft, 2010, Religion and Authority in the Public Sphere. Representations of Religion in Scandinavian Parliaments and Media, Aarhus, Aarhus University, Faculty of Theology.

CHRISTIE Nils, 2001, "Kriminalitetskontroll som industry" [Penalty control as industry], Samfunnsspeilet 15-3, pp. 13-20.

Dagbladet, 12 february 2010, “Advarte mot 11. September $i$ Norge” [Warned against September 11 in Norway], Available from http://www.dagbladet.no/2010/02/12/ nyheter/karikatur/utenriks/politikk/innenriks/10369255/ [Accessed November 9. 2010].

Esping-Andersen Gösta, 1990, The Three Worlds of Welfare Capitalism, Cambridge, Princeton, Polity Press, Princeton University Press.

FetZer Joel, Soper Cristopher, 2005, Muslims and the State in Britain, France, and Germany, Cambridge, Cambridge University Press.

Fridhov Inger Marie, Brandt Hilde, Røberg Viggo, Thorp Tone, TorjuUl Ragnhild Strøm, 1994, Organiseringen av prestetjenesten i fengslene [The organization of the prison chaplain services], Oslo, Justisdepartementet and Kirke-, utdannings- og forskningsdepartementet.

FurSETH Inger, 2001, Muslims in Norwegian Prisons and the Defence, Trondheim, coll. "KIFO Perspektiv", 15, Tapir.

-, 2003, "Secularization and the Role of Religion in State Institutions", Social Compass, 50, pp. 191-202.

-, 2006, "Flerreligiøsitet i norske fengsler" [Religious diversity in Norwegian prisons], in Kühle L., C. Lumholt, (eds.), Straffens menneskelige ansigt?, København, Anis, pp. 213-238.

-, 2009, "Livsfaseriter på sykehus og sykehjem” [Rituals in hospitals and nursing homes], in Thorson Plesner I., Døving C. A., (eds.), Livsfaseriter, Oslo, Samarbeidsrådet for tro og livssyn, pp. 93-104.

Horsti Karina, 2008, "Overview of Nordic Media Research on Immigration and Ethnic Relations. From Text Analysis to the Study of Production, Use and Reception”, Nordicom Review, 29-2, pp. 275-293.

JACOBSEn Brian A., 2009, "Denmark", in Nielsen J. S. et. al., Yearbook of Muslims in Europe, 1, Leiden, Brill, pp. 97-109.

JACOBSEn Christine M., LeIRVIK Oddbjørn, 2009, “Norway”, in Nielsen J. S. et. al., Yearbook of Muslims in Europe, 1, Leiden, Brill, pp. 257-266. 
Kirkens informasjonstjeneste, 2009, Årbok for Den norske kirke 2009 [Yearbook for the Church of Norway 2009], Oslo, Kirkens informasjonstjeneste.

Kulturdepartementet, 2009, Rundskriv V-13B/2009: Samarbeid on tros- og livssynstjenester i fengsel [Cooperation about faith and worldview services in prisons], Available from http://www.regjeringen.no/nb/dep/kud/dok/rundskriv/2009/rundskriv-v-13b2009.html?id= 571299 [Accessed February 26 2010]

KNAP Sigrid Ingeborg, GRAUNBøL Hans Monrad, 2007, Rapport vedrørende etniske minoriteter $i$ Vestre Fongsel [Report regarding ethnic minorities in Vestre prison], Available from www.kriminalforsorgen.dk/Default.aspx?ID=71 [Accessed March 10 2010]

Koenig Matthias, 2007, "Europeanising the Governance of Religious Diversity. An Institutionalist Account of Muslim Struggles for Public Recognition", Journal of Ethnic and Migration Studies, 33-6, pp. 911-932.

Kriminalforsorgen, 2005, Vedrørende etniske minoriteter i kriminalforsorgen [Regarding ethnic minoritie in the prison and probation service], Available from http://www. kriminalforsorgen.dk/ [Accessed March 16. 2010]

Kriminalforsorgen, 2006, Rapport om gejstlig betjening af indsatte, der tilhører andre trossamfund end den evangelisk-lutherske danske folkekirke [Report on clerical services outside the Evangelical Lutheran Church in Denmark], Available from http:// www.kriminalforsorgen.dk/Default.aspx?ID=156 [Accessed March 16. 2010]

Kriminalforsorgen, 2008, Statistikberetning 2008, Available from http://www.kriminal forsorgen.dk/Default.aspx?ID=71 [Accessed March 12. 2010]

Kriminalforsorgen, 2009, Prison and Probation Service-in brief, Available from http:// www.kriminalforsorgen.dk/Default.aspx?ID=29 [Accessed March 10. 2010]

Kriminalforsorgen, 2008, Årsmelding 2007, Available from http://img3.custompublish. com/getfile.php/690061.823.spcpbptdtf/arsmelding2007.pdf?return=www.kriminalom sorgen.no [Accessed 15 November 2010]

Kriminalforsorgen, 2010, Kriminalomsorgen, Available from http://www.kriminalom sorgen.no/ [Accessed 15 November 2010]

KüHLE Lene, 2004, Out of Many, One, Århus, Det Teologiske Fakultet.

-, 2006, "Religion i danske fængsler" [Religion in Danish prison], in Kühle L., Lomholt C., (eds.), Straffens menneskelige ansigt, Anis, Frederiksberg, pp. 199-211.

-, 2009, "De godkendte muslimske trossamfund og de andre" (The acknowledged Muslim communities and the others), Available from http://www.teo.au.dk/csr/rel-aarbog09 [Accessed March 10. 2010]

Larsson Göran, 2009, Islam in the Nordic and Baltic Countries, London, New York, Routledge.

Lappi-Seppälä Tapio, 2007, "Penal Policy in Scandinavia”, Crime and Justice, 36-1, pp. 217-295.

Martin David, 1979, A General Theory of Secularization, New York, Harper \& Row.

Maussen Marcel, 2006, The governance of Islam in Western Europe. A state of the art report, IMISCOE Working Paper No. 16, Available from http://imiscoe.org/publica tions/workingpapers/documents/Governanceoflslam-stateoftheart_000.pdf [Accessed November 1. 2009]

Minkenberg Michael, 2007, "Democracy and Religion. Theoretical and Empirical Observations on the Relationship between Christianity, Islam and Liberal Democracy", Journal of Ethnic and Migration Studies, 33-6, pp. 887-909. 
Modood Tariq, Triandafyllidou Anna, Zapata-Barrero Ricard, (éds.), 2006, Multiculturalism, Muslims and Citizenship. A European Approach, London, New York, Routledge.

NielSEN Jørgen, 2004, Muslims in Western Europe, Edinburgh, University Press.

Odeltingspreposisjon nr. 5, 2001, Lov om giennomføring av straff [The Execution of Sentences Act], Oslo.

REPSTAD Pål, 2002, Dype, stille, sterke, milde. Religiøs makt $i$ dagens Norge [Deep, quiet, strong, mild. Religious power in contemporary Norway], Oslo, Gyldendal.

RIIs Ole, 2007, "Religious Pluralism in a Danish and a Global Context", in Beyer P., Beaman L., (eds.), Religion, Globalization and Culture, Brill, Leiden, pp. 434-452.

SiIM Birte, SKJEIE Hege, 2008, "Tracks, intersections and dead end. Multicultural challenges to state feminism in Denmark and Norway", Ethnicities, 8, pp. 322-344.

Statistics Denmark, 2010a, Population 1 January, 1 April, 1 July and 1 October by member of national church and time, Available from http://www.statbank.dk/statbank5a/ default.asp?w=1024 [Accessed March 10. 2010]

Statistics Denmark, 2010b, "Population in parishes", Available from http://www.dst.dk/ HomeUK/Statistics/focus_on/focus_on_show.aspx?sci=566 [Accessed March 10. 2010]

Statistics Norway, 2008, Den norske kirke (Dnk). Medlemmer og kirkelige handlinger, etter bispedømme. 2005-2008 [Church of Norway, Members and clerical acts, according to diocese. 2005-2008], Available from http://www.ssb.no/kirke_kostra/tab-200906-16-01.html [Accessed February 26. 2010]

Statistics Norway, 2009a, Medlemmer i trus- og livssynssamfunn utanfor Den norske kyrkja, etter religion/livssyn. 1. januar. 2005-2009 [Members in faith and worldview communities outside the Church of Norway according to religion/worldview. January 1. 2005-2009], Available from http://www.ssb.no/trosamf/tab-2009-12-09-01.html [Accessed February 19. 2010]

Statistics Norway, 2009b, Noen hovedresultateter fra statistikk over fengslinger. 19602007 (some results from statistics on imprisonment. 1960-2007), Available from http://www.ssb.no/a_krim_tab/tab/tab-2009-02-26-52.html [Accessed February 26. 2010].

Stifoss-HAnsSen Hans, FurSeth Inger, (eds.), 2008, Mellom prinsipper og pragmatisme. Analyser av høringen om staten og Den norske kirke [Between principles and pragmatism. Analyses of the hearing on state and Church of Norway], Trondheim, coll. "KIFO Perspektiv", 18, Tapir. 


\section{Abstract}

The Lutheran churches of Denmark and Norway retain strong ties to the State and the Lutheran prison chaplaincy exists within the framework of the State churches in similar ways in both countries. The situation of Muslim chaplaincies is however very different in the two countries. In Denmark where general policies are not multicultural and where the relationship between State and church remains strong, the prison service has several prison imams employed and plans are to increase this further. In Norway where the relationship between church and State are moving towards a looser relationship and support for multicultural policies are stronger there are no Muslim prison chaplains.

Key words: Muslims, prisons, Denmark, Norway, imams.

\section{Résumé}

Les Églises luthériennes du Danemark et de la Norvège sont fortement liées avec leur État respectif et les aumôneries de prison sont organisées de manière similaire au sein des Églises d'État des deux pays. En revanche, la situation de l'assistance spirituelle musulmane est très différente dans les deux États. Au Danemark - où les politiques publiques générales ne sont pas multiculturelles et où les relations ÉgliseÉtat demeurent étroites - les services pénitentiaires emploient plusieurs imams en tant qu'aumôniers de prison et prévoient d'en engager davantage. En Norvège, où l'Église et l'État se dirigent vers une relation plus souple et où le soutien aux politiques multiculturelles est plus fort, il n'y a pas d'aumôniers de prison musulmans.

Mots-clés : musulmans, prisons, Danemark, Norvège, imams.

\section{Resumen}

Las iglesias luteranas de Dinamarca y de Noruega están fuertemente ligadas a su Estado en cada país y las capellanías de prisión se organizan de manera similar en el seno de las iglesias de Estado de sus países. Por el contrario, la situación de la asistencia espiritual musulmana es muy diferente en los dos estados. En Dinamarcadonde las políticas públicas generales no son multiculturales y donde las relaciones Iglesia- Estado siguen siendo estrechas- los servicios penitenciaros emplean a varios imanes en tanto que capellanes de la prisión y prevén incluso emplear aún más. En Noruega, donde la Iglesia y el Estado se dirigen hacia una relación más flexible y donde el sostén a las políticas multiculturales es más fuerte, no hay capellanes de prisión musulmanes.

Palabras clave: musulmanes, prisiones, Dinamarca, Noruega, imanes. 
